\title{
Antigenaemia during acute graft versus host disease
}

\author{
C Fegan, S K Jackson, J A Whittaker
}

\begin{abstract}
Aims-Animal studies have shown that antigens present within the gut play an important role in the development of acute graft versus host disease (GvHD) following allogeneic bone marrow transplantation (BMT). In previous studies, inert sugars have been found to penetrate the small bowel mucosa after conditioning therapy for BMT; endotoxaemia can also occur during acute GvHD. Data on absorption of antigenic proteins across the gut following BMT in humans have not been presented as yet.

Methods-Six patients undergoing allogeneic BMT were studied to determine whether enteric ovalbumin absorption increased or endotoxaemia developed during acute GvHD.

Results-Three patients had minimal antigenaemia and no detectable endotoxaemia before receiving conditioning therapy. At the onset of acute GvHD, however, much higher ovalbumin concentrations were detected in those patients with severe antigenaemia. Serum concentrations of specific antiovalbumin IgG and IgA, or antiendotoxin IgM or IgG had no bearing on detectable IgG or IgM ovalbumin or endotoxin concentrations.

In five of six patients, small bowel permeability increased, as tested by the lactulose/mannitol sugar absorption test, but detectable ovalbumin absorption increased in only three of these and only two developed endotoxaemia.

Conclusions-Antigens present within the gut can cross the mucosal epithelium during acute GvHD, probably resulting in an enhanced immune response.

(f Clin Pathol 1995;48:105-109)
\end{abstract}

Keywords: Acute graft versus host disease, antigenaemia, endotoxaemia.

Enteric microbial antigens are thought to play a role in the development of acute graft versus host disease (GvHD) as has been shown in both animal experiments ${ }^{1-3}$ and clinical studies. ${ }^{4-6}$ Antigens are thought to penetrate the mucosa following damage caused by conditioning therapy and sensitise donor lymphocytes to host antigens, enhancing the graft versus host reaction. Conditioning chemotherapy can damage the bowel mucosa for up to four weeks following transplantation, with acute GvHD also compromising barrier function. ${ }^{7}$ Indeed, we have shown previously that endotoxaemia is not unusual during acute GvHD. ${ }^{8}$

Absorption of tiny amounts of antigenic protein occurs in normal individuals and is thought to play an important role in the development of tolerance to gut derived antigens. ${ }^{9}$ The absorption of antigenic proteins is not well understood. Here, we describe the absorption of ovalbumin and endotoxin across the human small bowel mucosa following allogeneic bone marrow transplantation (BMT) at onset of acute GvHD.

\section{Methods}

The study population comprised patients entering the Bone Marrow Transplant Unit at the University Hospital of Wales, Cardiff. Patient details are presented in table 1.

All patients received the same conditioning therapy comprising cyclophosphamide $60 \mathrm{mg} /$ $\mathrm{kg}$ on two successive days followed by total body irradiation ( $1125 \mathrm{cGy}$ given in five fractions over three days at a rate of $5 \mathrm{cGy} /$ minute), were nursed in laminar flow rooms, and received gut decontamination therapy consisting of nystatin, amphotericin, colistin, and cotrimoxazole along with acyclovir. Initially, 18 patients were enrolled into the study but only six successfully completed the tests, almost entirely because of their refusal to repeat the ovalbumin test as this had a particularly bad taste and consistency. Lactulose/mannitol permeability tests and ovalbumin penetration studies were performed and plasma endotoxin/ antiendotoxin antibody concentrations determined before administration of conditioning therapy, at onset of GvHD and one day thereafter.

\section{OVALBUMIN PENETRATION STUDY}

Ovalbumin is a large phosphoglycoprotein with a molecular weight of 45000 and comprises $40 \%$ of total egg protein.

After an overnight fast, patients drank milk $(50 \mathrm{ml})$ containing gamma irradiated egg powder (equivalent to $6 \mathrm{~g}$ ovalbumin) over $15 \mathrm{~min}$ utes. Blood samples were taken from a central

MTX, methotrexate; AML, acute myeloid leukaemia; MRD, matched related donor; CML, myelodysplastic syndrome; ALL, acute lymphoblastic leukaemia; MDS, myelodysplastic syndrome. 
line before the test and subsequently at 30,60 , 120,180 , and 240 minutes after ingestion of the milk; the patients took nothing further by mouth during this period. Serum was prepared and stored in aliquots at $-60^{\circ} \mathrm{C}$ until analysed.

\section{DETECTION OF OVALBUMIN}

Polyclonal rabbit antiserum was prepared following inoculation with ovalbumin (Sigma, Poole, Dorset, UK). This was purified and labelled with biotin. An enzyme linked immunosorbent assay (ELISA) plate (Falcon) was coated with ovalbumin antisera (diluted 1 in 10000 ) and incubated overnight at $4^{\circ} \mathrm{C}$. The plate was washed three times in phosphate buffered saline (PBS)/Tween before the addition of $0.1 \%$ bovine serum albumin (BSA) in PBS over 15 minutes. After a further wash, a standard curve was constructed (ovalbumin 25 to $0.75 \mathrm{ng} / \mathrm{ml}$ ) and the patient samples added. This was incubated for one hour and after further washing, antiovalbumin/biotin was added (diluted 1 in 2000) for one hour. Again after washing, peroxidase labelled Streptavidin (Sigma) was added. After one hour, a final wash was performed and ortho-phenylene diamine added. This reaction was stopped after $30 \mathrm{~min}-$ utes with $2 \mathrm{M}$ sulphuric acid and the optical density was then measured at $492 \mathrm{~nm}$. All incubations were carried out at $37^{\circ} \mathrm{C}$ and all tests were performed in triplicate. The ELISA could detect $0.01 \mathrm{ng} / \mathrm{ml}$ ovalbumin with an intraassay coefficient of variation of $5.9 \%(25 \mathrm{ng} /$ $\mathrm{ml})$ and $6 \%(1.5 \mathrm{ng} / \mathrm{ml})$ and an interassay coefficient of variation of $5 \cdot 7 \%(25 \mathrm{ng} / \mathrm{ml})$ and $7 \%(1.5 \mathrm{ng} / \mathrm{ml})$.

\section{DETERMINATION OF ANTIBODIES AGAINST OVALBUMIN}

An ELISA plate was coated with ovalbumin $(10 \mathrm{ng} / \mathrm{ml})$ and incubated overnight at $4^{\circ} \mathrm{C}$. After washing three times (PBS/Tween), pooled human serum (diluted 1 in 100 in $1 \%$ BSA) was added to four wells as a standard. The patients' serum samples (diluted 1 in 10) were then added in doubling dilutions ( 1 in 10 to 1 in 5120) and incubated for one hour at $37^{\circ} \mathrm{C}$. After a further wash, antihuman IgG/ peroxidase (Sigma) (diluted 1 in 2000 in $0.1 \%$ BSA) was added to all wells for a further hour. A final wash was performed before the addition of orthophenylene diamine for 30 minutes; the reaction was stopped with $2 \mathrm{M}$ sulphuric acid. Optical density was then measured at $492 \mathrm{~nm}$. A similar method was used to estimate antiovalbumin IgA, but in this instance the pooled human serum was diluted 1 in 10 and antihuman IgA (diluted 1 in 2000; Sigma) was used. The titre was defined as that concentration of patient serum which equaled half the maximum of pooled human serum antiovalbumin activity.

\section{LACTULOSE/MANNITOL TEST}

After an overnight fast, the patients emptied their bladders and then drank a solution comprising $5 \mathrm{~g}$ mannitol, $5 \mathrm{~g}$ lactulose and $65 \mathrm{ml}$ water over five minutes. Urine was then col- lected over five hours. The patients were allowed to eat and drink two hours after starting the test. The total volume of urine passed was recorded and a $20 \mathrm{ml}$ aliquot was taken and stored at $-20^{\circ} \mathrm{C}$ until analysis was performed using the methods of Laker. ${ }^{1011}$ The per cent excretion of both lactulose and mannitol was measured and the results expressed as a ratio of lactulose to mannitol (normal range $<0 \cdot 02$ ). Mannitol (a monosaccharide, molecular weight 182 , radius $0.4 \mathrm{~nm}$ ) is passively absorbed transcellularly through aqueous pores in the epithelial cell membrane. A decrease in the urinary excretion of mannitol represents epithelial cell loss and a reduction in the cell surface area of the bowel (normal range of excretion $8-40 \%$ ). Lactulose (a non-digestable disaccharide, molecular weight 342 , radius $0.54 \mathrm{~nm}$ ) is passively absorbed through the intercellular tight junctions and the villous tip extrusion zone. An increase in lactulose excretion represents damage to the tight junctions (normal range of excretion $<0.3 \%$ ).

Expression of lactulose and mannitol excretion as a ratio means that changes in bowel transit time, gastric emptying or renal function do not alter the overall result as each of the probe molecules will be similarly affected.

\section{PLASMA ENDOTOXIN ASSAY}

Endotoxin was determined using the limulus chromogenic substrate assay kit (Quadratech, Surrey, UK), adapted for use on a sterile microtitre plate. Absorption at $405 \mathrm{~nm}$ was read on an ELISA plate reader (Labsystems) and results converted into $\mathrm{pg} / \mathrm{ml}$ endotoxin by linear regression analysis from standard curves generated with known endotoxin concentrations in standard plasma. This assay was found to be sensitive to less than $5 \mathrm{pg} / \mathrm{ml}$, specific and reproducible (interassay coefficient of variation $<5 \%)$.

\section{ANTIENDOTOXIN ANTIBODY ESTIMATION}

Antiendotoxin antibody estimation was performed using ELISA. Endotoxin antigens from Escherichia coli EH100, Salmonella minnesota Re595, Salmonella typhimurium SL684, and Shigella flexneri (all from Sigma) were mixed together to form a cocktail which was made up at $1 \mathrm{mg} / \mathrm{ml}$ in pyrogen free water. The cocktail was then diluted to $20 \mathrm{mcg} / \mathrm{ml}$ in $0.05 \mathrm{M}$ sodium bicarbonate ( $\mathrm{pH} \mathrm{9.8)} \mathrm{containing} 0.02 \mathrm{M}$ magnesium chloride, and $100 \mathrm{mcg}$ of this solution was added per well to alternate rows of a 96-well plate (Dynatech) and left to coat overnight at room temperature. After washing the plates in PBS, containing $0 \cdot 1 \%(\mathrm{v} / \mathrm{v})$ Tween $20,0.5 \%(\mathrm{w} / \mathrm{v})$ sodium azide and $0.02 \mathrm{M} \mathrm{mag}-$ nesium chloride, remaining binding sites were blocked by post-coating in $1 \%$ BSA in pyrogen free PBS for one hour at $37^{\circ} \mathrm{C}$. Patients' serum was added to the plates in duplicate at a 1 in 100 dilution in wash buffer containing 4\% polyethylene glycol $6000(\mathrm{w} / \mathrm{v})$ and 1\% BSA. The test serum samples were compared with a control serum made from a pool of over 100 normal blood donors, matched for age and sex, which was added at dilutions from 1 in 25 to 


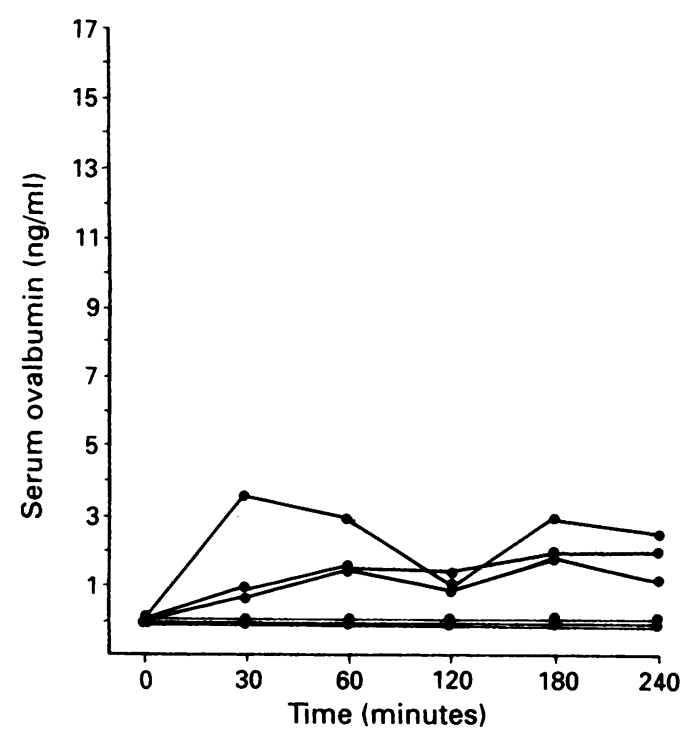

Figure 1 Serial serum ovalbumin concentrations before administration of conditioning therapy.

1 in 1600 in the same buffer. After incubation and washing, alkaline phosphatase conjugated antihuman IgG or IgM (Sigma) (diluted 1 in 500 or 1 in 1000) in the above buffer was added at $100 \mathrm{mcg}$ per well. Finally, $100 \mathrm{mcg}$ of $1 \mathrm{mg} / \mathrm{ml}$ substrate ( $\mathrm{p}$-nitrophenyl phosphate) (Sigma) were added per well in sodium carbonate/bicarbonate buffer $(\mathrm{pH} \mathrm{9.8).} \mathrm{The} \mathrm{re-}$ action was stopped with $50 \mathrm{mcg}$ per well sodium hydroxide $(1 \mathrm{~N})$ and the colour read on a spectrophotometer at $405 \mathrm{~nm}$ (Labsystems Multiscan). Absorbances for the test serum samples were converted to a percentage of the control sera (100\%).

\section{Results}

Before receiving conditioning therapy, none of the patients had detectable endotoxaemia, all had a normal lactulose/mannitol permeability test (table 2), but three patients had very low serum ovalbumin concentrations as early as 30 minutes after ingestion persisting for at least four hours (fig 1). Acute GvHD developed on the following days post-transplant: case 1 on day 17; case 2 on day 8; case 3 on day 10 ; case 4 on day 22; case 5 on day 10; case 6 on day 14 .

With the onset of acute GvHD, high serum ovalbumin concentrations were detected in three patients (fig 2) which seemed to correlate with lactulose excretion. Although patients with high ovalbumin concentration had higher grades of acute GvHD, it was not related to the degree of gut GvHD (tables 2 and 3).

There was no correlation between the detection of serum ovalbumin and the number of days that the test was performed following BMT. Indeed, case 4 was tested on day 23 following BMT and was found to have detectable ovalbumin concentrations. As all patients received exactly the same dose of chemotherapy, resulting gut damage probably does not account for the differences in detectable serum ovalbumin. Indeed, the gut is morphologically normal by 21 days unless acute GvHD has developed. ${ }^{12}$

Serum antiovalbumin IgA and IgG levels did not change between administration of conditioning therapy and the onset of acute GvHD. There was no correlation between serum antiovalbumin immunoglobulin concentration and ovalbumin penetration (tables 2 and 3 ).

Before conditioning therapy, two patients had detectable ovalbumin concentrations but this was no longer evident following the onset of acute GvHD. Two patients with detectable ovalbumin also developed endotoxaemia. Endotoxaemia was no longer detectable 24 hours after the onset of acute GvHD (data not shown). Again, the development of endotoxaemia did not seem to correlate with endotoxin antibody levels (table 3 ).

Table 2 Peak serum ovalbumin concentrations, antiovalbumin specific IgG and IgA levels and lactulose/mannitol excretion, and plasma endotoxin/antiendotoxin antibody levels before administration of conditioning therapy

\begin{tabular}{|c|c|c|c|c|c|c|c|c|c|}
\hline \multirow{2}{*}{$\begin{array}{l}\text { Patient } \\
\text { No. }\end{array}$} & \multirow{2}{*}{$\begin{array}{l}\text { Peak } \\
\text { Ovalbumin } \\
\text { (ng/ml) }\end{array}$} & \multicolumn{2}{|c|}{$\begin{array}{l}\text { Serum } \\
\text { Antiovalbumin }\end{array}$} & \multirow{2}{*}{$\begin{array}{l}\text { Plasma } \\
\text { endotoxin } \\
\text { (pg/ml) }\end{array}$} & \multicolumn{2}{|c|}{$\begin{array}{l}\text { Serum } \\
\text { Antiendotoxin }\end{array}$} & \multirow{2}{*}{$\begin{array}{l}\text { Mannitol } \\
\text { excretion } \\
(\%)\end{array}$} & \multirow{2}{*}{$\begin{array}{l}\text { Lactulose } \\
\text { excretion } \\
(\%)\end{array}$} & \multirow{2}{*}{$\begin{array}{l}\text { L:M } \\
\text { ratio }\end{array}$} \\
\hline & & $\operatorname{Ig} G$ & $\operatorname{Ig} A$ & & $\operatorname{Ig} G$ & $I g M$ & & & \\
\hline $\begin{array}{l}1 \\
2 \\
3 \\
4 \\
5 \\
6\end{array}$ & $\begin{array}{l}1 \cdot 8 \\
\text { Undetected } \\
3 \cdot 6 \\
2 \cdot 0 \\
\text { Undetected } \\
\text { Undetected }\end{array}$ & $\begin{array}{l}1 / 8 \\
1 / 128 \\
1 / 2 \\
1 / 16 \\
1 / 128 \\
1 / 16\end{array}$ & $\begin{array}{l}1 / 64 \\
1 / 8 \\
1 / 256 \\
1 / 64 \\
1 / 256 \\
1 / 4\end{array}$ & $\begin{array}{l}<5 \\
<5 \\
<5 \\
<5 \\
<5 \\
<5\end{array}$ & $\begin{array}{l}43 \cdot 2 \\
88 \cdot 4 \\
137 \\
62 \cdot 7 \\
22 \cdot 4 \\
66 \cdot 3\end{array}$ & $\begin{array}{l}29 \cdot 1 \\
60 \cdot 5 \\
42 \cdot 5 \\
48 \cdot 9 \\
38 \cdot 1 \\
40 \cdot 3\end{array}$ & $\begin{array}{r}13 \cdot 2 \\
18 \cdot 2 \\
0 \cdot 9 \\
6 \cdot 7 \\
19 \cdot 8 \\
20 \cdot 6\end{array}$ & $\begin{array}{l}0.07 \\
0.06 \\
0.01 \\
0.026 \\
0.05 \\
0.08\end{array}$ & $\begin{array}{l}0.005 \\
0.003 \\
0.011 \\
0.004 \\
0.002 \\
0.004\end{array}$ \\
\hline
\end{tabular}

L:M, lactulose:mannitol.

Table 3 Peak serum ovalbumin concentrations, antiovalbumin IgG and IgA levels and lactulose/mannitol excretion, and plasma endotoxin/ antiendotoxin antibody levels at the onset of GvHD with the grade of GvHD shown at the time of testing

\begin{tabular}{|c|c|c|c|c|c|c|c|c|c|c|c|c|}
\hline \multirow{3}{*}{$\begin{array}{l}\text { Patient } \\
\text { No. }\end{array}$} & \multicolumn{9}{|c|}{ At onset of acute GvHD } & & & \\
\hline & \multirow{2}{*}{$\begin{array}{l}\text { Peak } \\
\text { ovalbumin } \\
\text { (ng/ml) }\end{array}$} & \multicolumn{2}{|c|}{$\begin{array}{l}\text { Serum } \\
\text { antiovalbumin }\end{array}$} & \multirow{2}{*}{$\begin{array}{l}\text { Plasma } \\
\text { endotoxin } \\
(p g / m l)\end{array}$} & \multicolumn{2}{|c|}{$\begin{array}{l}\text { Serum } \\
\text { antiendotoxin }\end{array}$} & \multirow{2}{*}{$\begin{array}{l}\text { Mannitol } \\
\text { excretion } \\
(\%)\end{array}$} & \multirow{2}{*}{$\begin{array}{l}\text { Lactulose } \\
\text { excretion } \\
(\%)\end{array}$} & \multirow{2}{*}{$\begin{array}{l}\text { L:M } \\
\text { ratio }\end{array}$} & \multicolumn{3}{|c|}{ GvHD grade } \\
\hline & & $\operatorname{Ig} G$ & $\operatorname{Ig} A$ & & $\operatorname{Ig} G$ & $\operatorname{Ig} M$ & & & & Skin & Liver & Gut \\
\hline 1 & Undetected & $1 / 16$ & $1 / 2$ & $<5$ & $22 \cdot 2$ & $32 \cdot 1$ & $1 \cdot 0$ & 0.06 & 0.060 & 0 & 0 & 1 \\
\hline 2 & $9 \cdot 8$ & $1 / 64$ & $1 / 4$ & 26 & 121 & $59 \cdot 0$ & $4 \cdot 3$ & 0.36 & 0.003 & 2 & 1 & 1 \\
\hline 3 & Undetected & $1 / 32$ & $1 / 256$ & $<5$ & $51 \cdot 1$ & 35.0 & $4 \cdot 6$ & 0.02 & 0.004 & $0-1$ & 0 & 0 \\
\hline 4 & $11 \cdot 7$ & $1 / 16$ & $1 / 64$ & 25 & 92.9 & 108 & $5 \cdot 2$ & 0.47 & 0.090 & 2 & 2 & 0 \\
\hline 5 & 16.5 & $1 / 128$ & $1 / 8$ & $<5$ & 56.0 & $25 \cdot 0$ & $3 \cdot 4$ & 0.33 & 0.097 & 2 & 0 & 0 \\
\hline 6 & Undetected & $1 / 8$ & $1 / 2$ & $<5$ & $84 \cdot 0$ & 129 & $1 \cdot 2$ & 0.06 & 0.050 & 0 & 0 & 0 \\
\hline
\end{tabular}




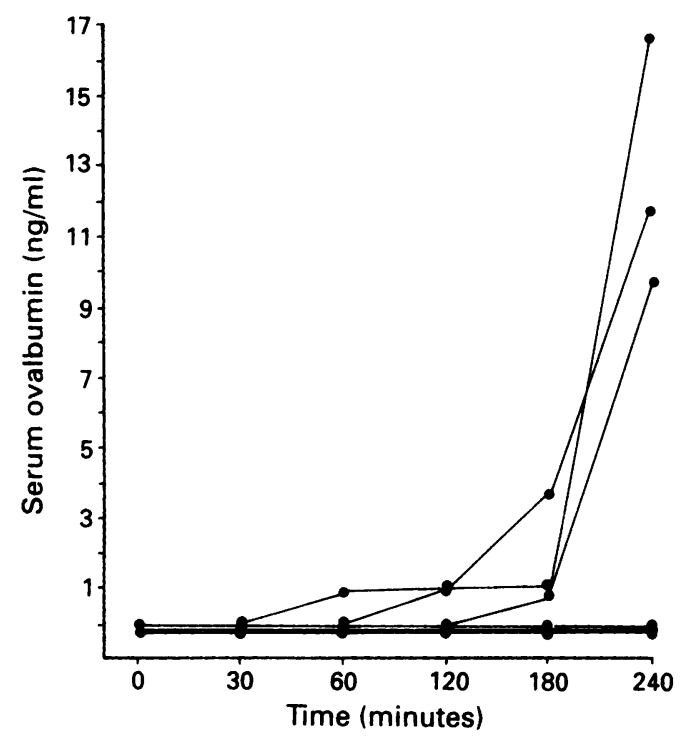

Figure 2 Serial serum ovalbumin concentrations at the onset of acute GvHD.

\section{Discussion}

Normally, small amounts of antigenic proteins are thought to penetrate the bowel, leading to the development of tolerance to these antigens. ${ }^{9}$ Bacterial antigens present within the gut lumen are thought to penetrate the bowel following conditioning chemoradiotherapy, sensitising donor lymphocytes to host antigens and thereby enhancing acute GvHD. ${ }^{1-3}$ Non-absorbable antibiotics reduce acute GvHD, probably by reducing the bacterial antigenic load. ${ }^{56}$ It has been assumed that conditioning therapy damages the gut mucosa, enabling antigens to penetrate but in this study we have shown that it is acute GvHD which induces antigenaemia and endotoxaemia.

Of the six patients with acute GvHD, five had an abnormal sugar permeability test but only three of these developed ovalbumin antigenaemia. The absorption of ovalbumin correlates with the excretion of lactulose suggesting that ovalbumin, like lactulose, enters through damaged interepithelial tight junctions. Although ovalbumin penetrated the gut mucosa in patients with severe, acute GvHD, this process was not simply related to the grade of gut GvHD. Patients with subclinical gut GvHD can have increased gut mucosal permeability. ${ }^{7}$

Increased antigen penetration will lead to inteferon- $\gamma$ release by lymphocytes which may not only increase the expression of HLA-DR by gut epithelial cells, but also render the interepithelial tight junctions more permeable permitting even more antigen to penetrate. ${ }^{1314}$ The magnitude of the immune response is determined by the amount of antigen penetration and the degree of HLA-DR expression. Thus, greater bowel permeability induced by GvHD may result in an even greater immune response. ${ }^{1516}$ It is also interesting to note that the magnitude of $\mathrm{T}$ cell migration into the gut epithelium is determined by the amount of intraluminal antigen. ${ }^{1718}$
We have previously shown that endotoxaemia is readily detectable during acute GvHD. ${ }^{8}$ Experimental evidence suggests that endotoxin can induce acute GvHD perhaps by the release of secondary cytokines such as tumour necrosis factor. ${ }^{19}$

Any antigen that penetrates the mucosa should be presented by antigen presenting cells to T4 helper cells leading to the release of antigen specific antibodies by plasma cells thus neutralising the antigen. ${ }^{20}$ During acute GvHD, antigen presenting cell and gut plasma cell numbers are reduced, particularly in severe disease, ${ }^{21}$ and therefore the efferent response to antigen penetration is impaired. In our study, however, there seems to be no simple correlation between antigen specific antibody levels and antigen penetration, confirming previous reports. ${ }^{9}$

During acute GvHD, there seemed to be a time lag before ovalbumin could be detected compared with that observed before transplantation. Some patients who had detectable concentrations before transplantation did not have acute GvHD at that time. All patients tested during acute GvHD were taking high dose corticosteroids which can reduce the passive absorption of bacterial antigens from the gut, including endotoxin, and may similarly affect obvalbumin absorption in patients with minimal mucosal damage. ${ }^{22}$

In conclusion, acute GvHD can result in antigens which usually reside in the gut gaining access to the systemic circulation resulting in an enchanced immune response.

1 Keast D, Walters MNI. The pathology of murine runting and its modification by neomycin sulphate lavages. Immunology 1968;15:247-62.

2 Pollard M, Chang CF, Srivastava KK. The role of microflora in development of graft versus host disease. Transplant Proc 1976;8:533-6.

3 van Bekkum DW, Knaan S. Brief communication: role of bacterial microflora in the development of intestinal lesions from graft versus host reaction. $\mathcal{F}$ Natl Cancer Inst 1977; from graft

4 Gratama JW, Stijnen T, Weiland HT, Hekker AC, de Gast $\mathrm{GC}, \mathrm{Zwaan} \mathrm{FE}$, et al. Herpes virus immunity and acute graft versus host disease. Lancet 1987;i:471-4.

5 Moller J, Skirhoj P, Hoiby N, Petersen FB. Copenhagen bone marrow transplantation group. Protection against graft versus host disease by gut sterilization? Exp Haematol 1982;10(Suppl 12):101-2.

6 Storb R, Prentice RL, Buckner CD, Clift RA, Appelbaum $\mathrm{F}$, Deeg J, et al. Graft versus host disease and survival in patients with aplastic anaemia treated by marrow grafts from HLA identical siblings. $N$ Engl $\mathcal{f}$ Med 1983;308: from 7 .

7 Fegan $\mathrm{C}$, Poynton $\mathrm{CH}$, Whittaker JA. The gut mucosal barrier in bone marrow transplantation. Bone Marrow Transplant 1990;5:373-7.

8 Jackson SK, Parton J, Barnes RA, Poynton $\mathrm{CH}$, Fegan C. Effect of IgM-enriched intravenous immunoglobulin (Pentaglobin) on endotoxaemia and anti-endotoxin antibodies in bone marrow transplantation. Eur 7 Clin Invest 1993;23:540-5.

9 Husby S, Jensenius JC, Svehag SE. Passage of undegraded dietary antigen into the blood of healthy adults. Quantification, estimation of size distribution and relation of uptake to levels of specific antibodies. Scand $\mathcal{F}$ Immunol
1985;22:83-92.

Laker MA. Estimation of disaccharides in plasma and urine by gas liquid chromatography. $\mathcal{F}$ Chromatogr 1979;163:

11 Laker MF, Mount JN. Mannitol excretion in biological fluids by gas liquid chromatography of trimethsilyl derivatives. Clin Chem 1980;26:441-3.

12 Epstein RJ, McDonald GB, Sale GE, Shulman HM, Thomas ED. The diagnostic accuracy of the rectal biopsy in acute graft versus host disease: a prospective study of thirteen patients. Gastroenterology 1980;78:764-71.

13 de Gast G, Gratama JW, Ringden D, Gluckman E. The multifactorial etiology of graft versus host disease. Immunol Today 1987;8:209-12.

14 Madara JL, Stafford J. Interferon-gamma directly affects barrier function of cultured intestinal epithelial monolayers. F Clin Invest 1989;83:724-7. 
15 Matis LA, Glimcher LH, Paul WE, Schwartz RH. Magnitude of response of histocompatibility-restricted T-cell clones is a function of the product of the concentration of antigen and Ia molecules. Proc Natl Acad Sci USA 1983; 80:6019-23.

16 Janeway CA, Bottomly K, Babich J, Conrad P, Conzen S, Jones $\mathrm{B}$, et al. Quantitive variation in antigen expression plays a central role in immune regulation. Immunol Today 1984;5:99-105.

17 Ferguson A, Parrott DMV. The effect of antigen deprivation on thymus-dependent and thymus-independent lymphocytes in the small intestine of the mouse. Clin Exp Immunol 1972;12:477-88.

18 Leigh RJ, Marsh MN, Crowe P, Kelly C, Garner V, Gordon D. Studies of intestinal lymphoid tissue. IX.
Dose-dependant, gluten induced lymphoid infiltration of coeliac jejunal epithelium. Scand F Gastroenterol 1985; 20:715-19.

19 Cohen J. Cytokines as mediators of graft versus host disease. Bone Marrow Transplant 1988;3:193-7.

20 Brandztaeg P, Sollid LM, Thrane PS, Kvale D, Bjerke K Scott H. Lymphoepithelial interactions in the mucosal immune system. Gut 1988;29:1116-30.

21 Beschorner WE, Yardley JH, Tutschka P, Santos GW. Deficiency of intestinal immunity with graft vs host disease in humans. F Infect Dis 1981;144:38-46.

22 Gaffin SL, Gathirim P, Wells MT, Brock-Vitney JG. Effect of cortico-steroid prophylaxis on lipopolysaccharide levels associated with intestinal ischaemia in cats. Crit Care Med 1986;14:889-91. 